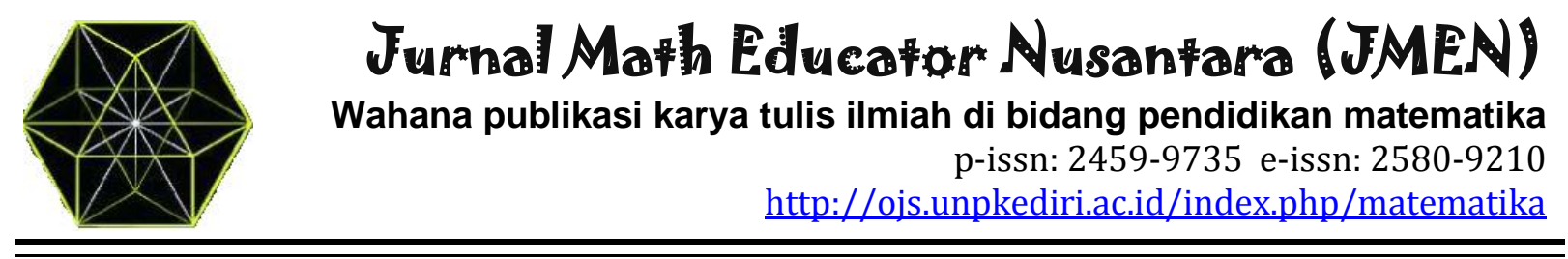

\title{
Peningkatan pemahaman konsep matematik mahasiswa melalui model pembelajaran active knowledge sharing
}

\author{
Novi Mayasari ${ }^{1}{ }^{*}$, Ahmad Kholiqul Amin ${ }^{2}$, Lailatur Rofiqoh ${ }^{3}$ \\ 1,2,3 Program Studi Pendidikan Matematika, IKIP PGRI Bojonegoro. Jalan Panglima Polim No 46 Kota \\ Bojonegoro, Indonesia. \\ E-mail: ${ }^{1}$ mahiraprimagrafika@gmail.com, ${ }^{2}$ choliqamin@gmail.com, ${ }^{3}$ lailaturrofiqoh@gmail.com. \\ * Korespondensi Penulis.
}

Article received : 08 Nov 2019, article revised : 14 Nov 2019, article published: 16 Nov 2019

\begin{abstract}
Abstrak: Penelitian ini merupakan Penelitian Tindakan Kelas yang bertujuan untuk meningkatkan kemampuan pemahaman konsep matematik mahasiswa tingkat II Semester 4 Pada Mata Kuliah Persamaan Differensial dengan menerapkan model pembelajaran Active Knowledge Sharing di IKIP PGRI Bojonegoro Tahun Pelajaran 2018/2019. Subjek dalam penelitian ini terdiri dari 26 orang mahasiswa.. Siklus pertama dilaksanakan sebanyak tiga pertemuan dan siklus ke-2 sebanyak tiga pertemuan. Instrumen yang digunakan adalah observasi, dokumentasi, dan, wawancara. Dokumentsi dari data hasil tes kemampuan pemahaman konsep matematik. Observasi digunakan untuk mengumpulkan data selama proses pembelajaran berlangsung, tes kemampuan pemahaman konsep matematik digunakan untuk mengetahui capaian masiswa pada setiap siklus, dan Wawancara diberikan kepada mahasiswa tertentu yang isinya berupa tanggapan serta respon terhadap pembelajaran pesamaan differensial dengan model pembelajaran Active Knowledge Sharing. Data dianalisis secara kuantitatif dan deskriptif. Hasil penelitian menunjukkan bahwa nilai rata-rata mahasiswa tingkat II semester 4 pada tes siklus pertama adalah 66,35 dan pada tes siklus ke-2 sebesar 87,31. Hasil penelitian menunjukkan bahwa pada siklus II pembelajaran dengan menerapkan Active Knowledge Sharing dapat meningkatkan kemampuan pemahaman konsep matematik mahasiswa.
\end{abstract}

Kata Kunci: Active Knowledge Sharing; pemahaman konsep; konsep matematik

\section{Increased understanding of student mathematical concepts through the active knowledge sharing learning model}

Abstract: This research is a Classroom Action Research which aims to improve the ability to understand mathematical concepts of second semester Semester 4 students on Differential Equation Courses by applying Active Knowledge Sharing learning models at IKIP PGRI Bojonegoro Academic Year 2018/2019. The subjects in this study consisted of 26 students. The first cycle was conducted in three meetings and the second cycle was three meetings. The instruments used were observation, documentation, and interviews. Documentation of the test results of the ability to understand mathematical concepts. Observations are used to collect data during the learning process, tests of understanding of mathematical concepts are used to determine student achievement in each cycle, and interviews are given to certain students in the form of responses and responses to differential learning with Active Knowledge Sharing learning models. Data were analyzed quantitatively and descriptively. The results showed that the average score of 4th semester II grade students on the first cycle test was 66.35 and in the second cycle test was 87.31. The results showed that in the second cycle of learning by applying Active Knowledge Sharing can improve the ability to understand students' mathematical concepts.

Keywords: Active Knowledge Sharing; understanding of concepts; mathematical concepts

\section{PENDAHULUAN}

Pendidikan bagi manusia merupakan sarana yang paling penting dalam mengembangkan bakat, minat, dan kemampuan pribadi. Pendidikan merupakan usaha yang dijalankan oleh seseorang atau kelompok orang lain agar mencapai tingkat hidup atau 
penghidupan yang lebih tinggi dalam arti mental (Hasbullah, 2011; Ariasa, Wiyasa, \& Kristiantari, 2014). Pendapat tersebut menyiratkan bahwa pendidikan dapat menanamkan nilai-nilai yang positif dalam kehidupan sehingga dapat meningkatkan kualitas hidup. Melalui pendidikan kita dapat memperoleh ilmu pengetahuan, mengembangkan karakter dan nilainilai yang positif dalam diri. OLeh karena itu pendidikan sangatlah penting baik ditingkat SD sampai dengan Perguruan tinggi, salah satunya dalam mata pelajaran matematika. Dan berdasarkan hasil wawancara dengan bapak Sujiran dosen yang mengampu mata kuliah persamaan differensial pada semester sebelumnya beliau menjelaskan bahwasanya terdapat beberapa Faktor yang menyebabkan rendahnya kemampuan pemecahan masalah matematika mahasiswa, salah satu faktornya yang berkaitan dengan model pembelajaran yang digunakan, misalnya model pembelajaran yang masih terpusat pada dosen, sementara mahasiswa cenderung pasif.

Berdasarkan hasil wawancara dengan beberapa dosen yang mengajar mata kuliah persamaan differensial, model pembelajan yang diterapkan adalah model pembelajaran langsung. Menurut Kardi (dalam Juliandri, 2017), Model pembelajaran langsung adalah suatu model pembelajaran dari pendekatan yang bersifat Teacher Center. Kurangnya kreatifitas dan inovasi para guru dalam mengembangkan dan menciptakan metode pembelajaran, membuat proses pembelajaran di kelas membosankan bagi mahasiswa (Jatmiko, 2018).

Dari permasalahan yang telah dipaparkan di atas, memberikan inspirasi untuk menerapkan salah satu model pembelajaran inovatif yang dapat meningkatkan konsep pemahaman mahamahasiswa matematka pada mata kuliah kalkulus. Solusinya ialah Menerapkan model pembelajaran Active Knowledge Sharing, karena metode pembelajaran ini mahasiswa terlibat langsung dalam kegiatan pembelajaran dan dalam membangun konsep materinya. Model pembelajaran Active Knowledge Sharing sangat diperlukan dalam memahami konsep materi pada mata kuliah persamaan differensial secara konsep, Karena apabila mahasiswa tidak dilibatkan secara langsung dalam proses pembelajaran ada kecenderungan untuk cepat melupakan materi persamaan differensial yang diajarkan oleh dosen. Active Knowledge sharing adalah cara yang bagus untuk menarik peserta didik dengan segera kepada materi pelajaran (Hamruni, 2009). Guru dapat menggunakannya untuk mengukur tingkat pengetahuan para peserta didik selagi, pada saat yang sama, melakukan beberapa bangunan tim (team building). Strategi ini bekerja dengan beberapa pembelajaran dan dengan beberapa materi pembelajaran.

Menurut zaini (dalam Ni'mah, 2017) active knowledge sharing merupakan merupakan model pembelajaran yang dapat membawa peserta didik untuk lebih siap belajar materi sebelum materi diajarkan dan melatih peserta didik untuk membentuk kerja sama tim. Hal ini sangat baik digunakan pada peserta didik yang mempunyai sifat individualisme yang kurang bekerjasama dalam diskusi. Jeon, Kim, \& Koh (2011) menjelaskan bahwa model pembelajaran Active Knowledge Sharing merupakan model yang menekankan peserta didik untuk saling membantu menjawab pertanyaan yang tidak diketahui oleh teman lainnya yang artinya bahwa peserta didik yang tidak menjawab pertanyaan diberi kesempatan untuk mencari 
jawaban dari teman yang mengetahui jawaban tersebut. Kemudian peserta didik yang mengetahui jawaban ditekankan untuk membantu yang kesulitan . Oleh karenanya Dosen diminta untuk pandai memilih metode agar tujuan pembelajaran dapat tercapai dengan baik. Salah satu cara untuk meningkatkan pemahaman konsep matematika mahasiswa dengan menerapkan model pembelajaran Active Knowledge Sharing (pembelajaran pengetahuan aktif) dapat membawa mahasiswa untuk siap belajar materi persamaan Differensial dengan cepat. Model pembelajaran ini diduga dapat meningkatkan kemampuan akademis mahasiswa dalam hal ini konsep pemahaman mahasiswa matematika.

Model pembelajaran ini mendorong dosen terlebih dahulu memberikan pertanyaan berupa daftar pertanyaan yang nantinya berkaitan dengan materi persamaan differensial. Oleh karenanya mahasiswa diminta untuk menyelesaikan dan jika ada pertanyaan yang belum dijawab maka diharuskan mereka untuk berdiskusi dengan yang lainnya. Dengan model ini diharapkan para mahasiswa dapat memahami konsep matematika dan dapat berperan aktif dalam pembelajaran matematika khusunya pada mata kuliah persamaan differensial. Selain itu kelebihan dari model pembelajaran ini adalah dapat meminta bantuan dari mahamahasiswa yang lain untuk menjawab pertanyaan yang tidak bias dijawab dan bias divariasikan dengan pemberian kartu indeks pada tiap mahasiswa untuk menuliskan informasi yang baru dari materi yang telah dipelajari.

Penelitian yang pernah dilakukan oleh (Mutmainah, 2015) dengan judul Pengaruh Strategi Active Knowledge Sharing Terhadap pemahaman konsep matematik mahasiswa, kesimpulan dari penelitian tersebut adalah bahwa pembelajaran matematika dengan menggunakan strategi active knowledge sharing berpengaruh terhadap pemahaman konsep matematik. Hal inilah yang melatar belakangi penelitian dengan judul "Peningkatan Pemahaman Konsep Matematik Mahasiswa Matematika Melalui Model Pembelajaran Active Knowledge Sharing di IKIP PGRI Bojonegoro". Hal yang sama diungkapkan oleh (Ariasa, dkk, 2014) dalam penelitiannya menyimpulkan bahwa terdapat pengaruh signifikan model pembelajaran Active Knowledge Sharing terhadap hasil belajar matematika pada mahasiswa kelas V SD Gugus Peliatan Ubud tahun ajaran 2013/2014.

Bedasakan latar belakang tersebut maka Tujuan dari penelitian ini adalah untuk mengetahui bagaimana penerapan model Active knowledge sharing pada pembelajaran persamaan Differensial di tingkat II Semester II Pada Mata Kuliah Persamaan differensial di IKIP PGRI Bojonegoro Tahun Pelajaran 2018/2019. Dan untuk mengetahui Seberapa besar peningkatan tingkat pemahaman konsep matematik mahasiswa pada pembelajaran Persamaan Differensial di tingkat II Semester II di IKIP PGRI Bojonegoro Tahun Pelajaran 2015/2016 setelah penerapan model pembelajaan Active knowledge sharing.

\section{METODE}

Jenis Penelitian yang penulis gunakan adalah jenis Penelitian Tindakan Kelas (Classroom Action Research). Adapun yang menjadi subyek penelitian dalam penelitian ini adalah 
Mahasiswa matematika tingkat 2 semester 4 pada mata kuliah Persamaan Differensial IKIP PGRI Bojonegoro dengan jumlah 26 mahasiswa. Penelitian dilaksanakan dalam 2 siklus tindakan yaitu siklus pertama dilaksanakan sebanyak 3 kali pertemuan dan siklus kedua dilaksanakan sebanyak 3 kali pertemuan.

Pengumpulan data dilakukan dengan observasi, wawancara, dan dokumentasi. Analisis data dilakukan dengan memberikan makna terhadap data yang berhasil dikumpulkan yakni makna dan proses pembelajaran sebagai upaya meningkatkan kemampuan pemahaman konsep matematik melalui tindakan yang dilakukan, dan dari makna itulah ditarik kesimpulan. Dalam penelitian ini menggunakan kuantitatif dan deskriptif statistik sederhana untuk membantu mengungkap data. Pemeriksaan keabsahan data dilakukan dengan mengadakan triangulasi. Triangulasi dilakukan dengan membandingkan data hasil observasi, wawancara, dan dokumentasi. Adapun urutan kegiatan penelitian mencakup: (1) perencanaan, (2) pelaksanaan, (3) observasi, dan (4) refleksi. Dibaah ini adalah gambar desain penelitian PTK.

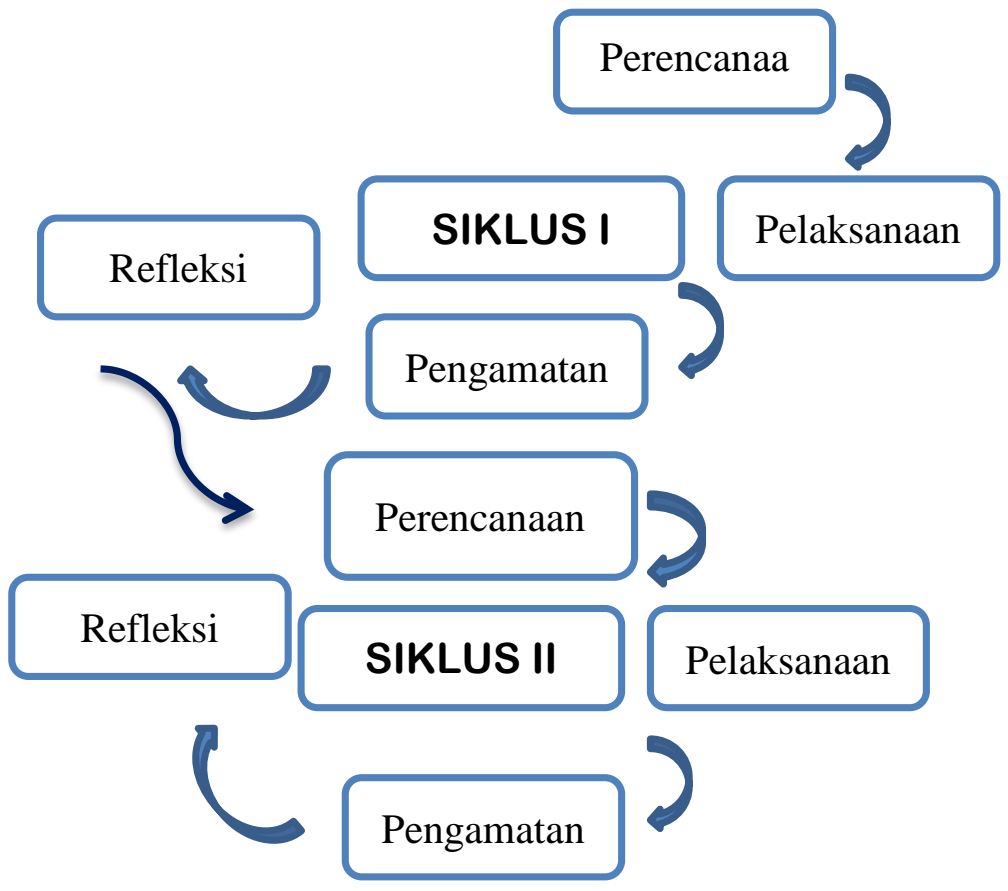

Gambar 1. Desain Penelitian

Berikut ini adalah Prosedur atau langkah-langkah yang akan peneliti lakukan dalam penelitian ini diantarannya meliputi Tahap persiapan yaitu peneliti melakukan observasi untuk mengetahui permasalahan di kelas terkait dengan pembelajaran persamaan differensial. Setelah observasi kemudian peneliti menganalisis dan menemukan pemecahan masalah dengan menggunakan model pembelajaran Active Knowledge Sharing.

Tahap Perencanaan yaitu Penelitian tindakan kelas ini akan dilaksanakan sebanyak dua siklus. Satu siklus terdiri dari tiga pertemuan. Adapun persiapan yang dilakukan untuk pelaksanaan tindakan siklus I diantaranya : Peneliti membuat kesepakatan untuk menetapkan materi pokok, Menetapkan hari dan tanggal penelitian, Pembuatan rencana pelaksanaan 
pembelajaran (RPP), Persiapan lembar observasi pembelajaran untuk setiap berlangsungnya pembelajaran, Menyusun pedoman wawancara dan tes mahasiswa untuk mengetahui tingkat pemahaman konsep matematik.

Tahap Pelaksanaan Tindakan yaitu menerapkan model pembelajaran Active Knowledge Sharing; Tahap Observasi yaitu mengamati setiap tindakan yang dilaksanakan meliputi aktivitas yang dilakukan peneliti dan mahasiswa selama kegiatan pembelajaran berlangsung. dan Tahap Refleksi yaitu tahap menganalisis dan mengevaluasi tindakan yang sudah dilaksanakan sehingga dapat dijadikan sebuah refleksi dalam menyusun siklus berikutnya untuk mengetahui pemahaman konsep matematik mahasiswa telah mencapai target yang ditentukan yaitu dengan kategori minimal $75 \%$. Penilaian ini dilihat dari hasil tes mahasiswa serta wawancara yang didukung data dari hasil observasi selama penelitian.

Kegiatan yang dilaksanakan pada siklus II merupakan perbaikan dari kegiatan yang telah dilaksanakan pada siklus I. Adapun tahapan siklus II yang dilalui sama seperti pada siklus I, meliputi perencaaan tindakan, pelaksanaan tindakan, pengamatan, dan refleksi. Jika belum terjadi peningkatan, maka siklus dapat dilanjutkan. Pada penelitian ini instrumen yang digunakan adalah Rencana Pelaksanaan Pembalajaran (RPP), Buku paket, butir-butir soal evaluasi, format penilaian, lembar wawancara dan lembar observasi.

Selanjutnya, indikator keberhasilan yang digunakan pada penelitian adalah apabila telah mencapai persentase minimal $75 \%$ dari keseluruhan mahasiswa yang diberi tindakan mampu mencapai nilai batas tuntas (KKM) yaitu skor 70. Nilai-nilai ini diperoleh berdasarkan hasil penyelesaian butir-butir soal evaluasi. Selain itu, berdasarkan hasil observasi dijadikan sebagai dasar untuk mengamati indikator keberhasilan pada penelitian ini bertujuan untuk mengetahui aktivitas mahasiswa dalam memahami materi yang disampaikan oleh dosen dan tim peneliti. Evaluasi dilaksanakan setelah terlaksananya pembelajaran pada siklus pertama. Berdasarkan hasil evaluasi pada siklus pertama, dilakukan perbaikan rencana pembelajaran yang diterapkan pada siklus kedua. Setelah siklus kedua terlaksana, diadakan evaluasi untuk mengetahui peningkatan kemampuan pemahaman konsep matematik mahasiswa. Setelah mahasisa menjaab butir-butir soal evaluasi, dan tim peneliti melakukan penilaian. Serta Tim peneliti melakukan evaluasi pada jawaban lembar observasi mahasiswa dengan tujuan untuk mengetahui aktivitas mahasiswa dalam menyerap materi yang disampaikan oleh dosen.

Evaluasi diadakan setelah terlaksananya pembelajaran siklus pertama. Berdasarkan hasil evaluasi pada siklus pertama, dilakukan perbaikan rencana pembelajaran yang diterapkan pada siklus kedua. Setelah siklus kedua terlaksana, diadakan evaluasi untuk mengetahui peningkatan hasil kemampuan pemahaman konsep matematik mahasiswa. Berdasarkan hasil tes kemampuan pemahaman konsep matematik mahasiswa dan lembar observasi dilanjutkan dengan proses Analisis data. Dan Analisis data yang digunakan dalam penelitian ini menggunakan metode yang bersifat deskriptif kuantatif yaitu mendeskripsikan data yang diperoleh melalui instrumen penelitian. Setelah data terkumpul, kemudian diklasifikasikan ke dalam dua kelompok data yaitu kuantitatif yang berbentuk angka-angka dengan menggnakan N-Gaint dan data kualitatif yang dinyatakan dalam kata-kata atau simbol. 
Data deskriptif yang peneliti gunakan yaitu wawancara langsung kepada responden. Data yang digunakan berupa informasi tentang kalimat yang memberikan pemahaman terhadap proses pembelajaran yang telah dilaksanakan, metode pembelajaran baru, aktivitas mahasiswa dan antusias dalam mengikuti pembelajaran. Berikut adalah beberapa tahapan yang dilakukan oleh peneliti dalam menganalisis data diatarannya sebagai berikut: Tahap pertama yaitu pengumpulan data ; Tahap kedua yaitu reduksi data: merangkum, memilih halhal yang pokok, menfokuskan pada hal yang penting. Tahap ini dilakukan untuk memberikan gambaran yang jelas, mempermudah peneliti melakukan pengumpulan data, dan mencari hasilnya dengan rumus N-Gaint.

$$
\mathrm{N}-\text { Gaint }=\frac{\text { Skor post test }- \text { Skor pre test }}{\text { Skor Ideal }- \text { Skor pre test }}
$$

Dengan Kategori:

G Tinggi $=$ nilai $(g)>0,70$

G sedang $=$ nilai $0,70>(\mathrm{g})>0,30$

$\mathrm{G}$ rendah $=$ nilai $(\mathrm{g})<0,30$

Dalam menganalisis data kemampuan pemahaman konsep matematik menggunakan analisis deskrpitif dari setiap siklus dengan menggunakan nilai posstest dibandingkan dengan nilai kriteia ketuntasan (KKM) dan nilai selisih pertemuan pertama, pertemuan kedua, dan pertemuan ketiga untuk melihat peningkatan kemampuan pemahaman konsep matematik mahasiswa tingkat 2 semester 4 di IKIP PGRI Bojonegoro yang memperhitungkan ketuntasan. Nilai yang diperoleh dari hasil perhitungan, kemudian disesuaikan dengan klasifikasi taraf ketecapaian.

Tabel.1 klasifikasi taraf ketercapaian

\begin{tabular}{cccc}
\hline No & Rentang Skor & Huruf & Klasifikasi \\
\hline 1 & $80-100$ & A & Tinggi Sekali \\
2 & $70-79$ & B & Tinggi \\
3 & $60-69$ & C & Sedang \\
4 & $50-59$ & D & Rendah \\
5 & $<50$ & E & Rendah Sekali \\
\hline
\end{tabular}

Tahap Ketiga, Display data yaitu data yang telah direduksi disajikan dalam bentuk uraian singkat yang bersifat naratif dan tabel; Tahap Keempat, Kesimpulan yaitu kesimpulan ini untuk melihat apakah tujuan dari proses pembelajaran sudah tercapai atau belum. Jika belum tercapai maka diadakan tindak lanjut (penelitian ulang), namun jika sudah berhasil maka penelitian dihentikan.

Tahap Kelima, Terakhir yaitu Indikator keberhasilan Adapun Komponen yang dijadikan indikator keberhasilan tercapainya peningkatan kemampuan pemahaman matematik 
mahasiswa pada saat melaksanakan kegiatan belajar mengajar pada penelitian ini adalah Antusias dari mahasiswa selama mengikuti pembelajaran; Perhatian dalam mengikuti pembelajaran; Semangat mahasiswa selama mengikuti pembelajaran.

\section{HASIL DAN PEMBAHASAN}

Penelitian ini merupakan penelitian tindakan kelas yang dilaksanakan di IKIP PGRI Bojonegoro pada mata kuliah persamaan differensial. Subyek dalam penelitian ini adalah seluruh mahasiswa tingkat 2 semester 4 sebanak 26 mahasiswa. Penelitian dilaksanakan pada tanggal 25 mei 2019 sampai dengan 30 juni 2019, dan dilakukan selama 2 kali siklus. Siklus I dilaksanakan sebanyak 3 kali pertemuan, dan siklus II dilaksanakan sebanyak 3 kali pertemuan. Adapun urutan kegiatan penelitian dari setiap siklus mencakup: (1) perencanaan, (2) pelaksanaan, (3) observasi, dan (4) refleksi.

Pelaksanaan pada siklus I (dilaksanakan sebanyak 3 kali pertemuan)

a) Perencanaan Tindakan

Berikut merupakan uraian kegiatan yang dilaksanakan pada tahap perencanaan tindakan siklus I:

1) Peneliti menyiapkan materi bahan ajar yang harus dikerjakan siswa dengan membuat soal essay untuk pree test dan post test meliputi materi: Persamaan diferensial linier tingkat satu derajat satu, persamaan differensial tingkat $\mathrm{N}$, persamaan differensial tingkat 1 derajat $\mathrm{N}$.

2) Membuat silabus dan RPP.

3) Mengarahkan mahasiswa agar membentuk kelompok sebanyak 3-4 orang dalam satu kelompok.

b) Pelaksanaan Tindakan (dilakukan sebanyak 3 kali pertemuan)

1) Pertemuan Pertama (Selasa, 14 Mei 2019) berlangsung selama 3 sks $=150$ menit. Pada petemuan pertama ini peneliti melakukan kegiatan pembelajaran dengan menerapkan model pembelajaran Active knowledge sharing Materi yang dibahas meliputi Persamaan diferensial linier tingkat satu derajat satu, persmaan differensial tingkat $\mathrm{N}$, persamaan differensial tingkat 1 derajat $\mathrm{N}$, sebelum penelitian dimulai dosen selaku peneliti dan dan memberikan soal essay berupa preetest kepada mahasiswa dengan tujuan untuk mengukur tingkat pemahaman konsep mahasiswa. Pada proses pelaksanaan pada saat pembelajaran dengan menerapkan model pembelajaran terlihat mahasiswa sangat antusias. Hal tersebut dapat dibuktikan berdasarkan pengamatan yang dilakukan peneliti dan tim pada saat pelaksanaan tindakan.

2) Pertemuan kedua (selasa, 21 Mei 2019) Pada pertemuan kedua ini, pelaksanaan pembelajaran sama dengan pertemuan kesatu yaitu dengan menerapkan model pembelajaran active knowledge sharing, tetapi ada perbedaan dari segi mahasiswa telihat antusias tapi ada sebagian kecil yang tidak memamahi sintaks 
dan tidak memperhatikan. Hal tersebut dapat dibuktikan berdasarkan pengamatan yang dilakukan peneliti dan tim pada saat pelaksanaan tindakan.

3) Pertemuan ketiga (selasa, 28 Mei 2019) Pada pertemuan ketiga ini, pelaksanaan pembelajaran dengan menerapkan model pembelajaran active knowledge sharing, dimana mahasiswa lebih bersemangat dalam mengikuti pembelajaran, tetapi masih ada beberapa mahasiswa yang tidak fokus pada saat pembelajaran. Di akhir pembelajaran peneliti dan tim memberikan soal post test pada siklus pertama kepada seluruh mahasiswa dalam bentuk essay sebanyak 10 soal. Test dikerjakan secara individu dengan tujuan untuk mengetahui tingkat kemampuan pemahaman konsep matematik mahasiswa pada mata kuliah persamaan differensial. Hal tersebut dapat dibuktikan berdasarkan pengamatan yang dilakukan peneliti dan tim pada saat pelaksanaan tindakan.

c) Tahap ketiga, Pengamatan Pada tahapan ini dilakukan observasi dengan menggunakan lembar observasi terhadap pelaksanaan tindakan-tindakan yang sudah dilakukan pada siklus I serta didapatkan hasil wawancara dengan mahasiswa dan hasil tes kemampuan pemahaman konsep matematik pada mata kuliah persamaan differensial.

Berikut ini adalah data dari hasil. Observasi, wawancara dan tes kemampuan pemahaman konsep matematika mahasiswa: Lembar Observasi Mahasiswa.

Tabel 2. Hasil observasi Aktivitas Mahasiswa pada siklus I.

\begin{tabular}{|c|c|c|c|c|c|}
\hline \multirow[t]{2}{*}{ No } & \multirow[t]{2}{*}{ AspekYang diamati } & \multicolumn{4}{|c|}{ SKOR } \\
\hline & & SB & B & $\mathrm{C}$ & $\mathrm{K}$ \\
\hline 1 & Kesiapan Menerima Pembelajaran & $\sqrt{ }$ & & & \\
\hline 2 & $\begin{array}{l}\text { Mendengarkan penjelasan tentang kompetensi } \\
\text { yang hendak dicapai }\end{array}$ & $\sqrt{ }$ & & & \\
\hline 3 & Mengikuti proses pembelajaran & & $\sqrt{ }$ & & \\
\hline 4 & Keterlibatan dalam pembelajaran & & $\sqrt{ }$ & & \\
\hline 5 & $\begin{array}{l}\text { Interaksi antara Peneliti, mahasiswa, dan materi } \\
\text { pembelajaran. }\end{array}$ & & & $\sqrt{ }$ & \\
\hline 6 & $\begin{array}{l}\text { Mengemukakan pendapat ketika diberikan } \\
\text { kesempatan untuk bertanya }\end{array}$ & & & $\sqrt{ }$ & \\
\hline 7 & Kerjasama tim & & & $\sqrt{ }$ & \\
\hline \multicolumn{2}{|c|}{ Jumlah } & \multicolumn{4}{|c|}{20} \\
\hline \multicolumn{2}{|c|}{ Prosentase } & \multicolumn{4}{|c|}{71,43} \\
\hline \multicolumn{2}{|c|}{ Kualifikasi } & \multicolumn{4}{|c|}{ Baik } \\
\hline
\end{tabular}

Hasil observasi menjelaskan bahwa skor yang diperoleh dari bebapa aspek diperoleh 20 , dan prosentase diperoleh $71,43 \%$ dengan kategori baik perlu dilakukan perbaikan khususnya pada aspek point 5-7 karena masih mendapatkan skor dalam kategori baik. Ada beberapa alasan yang menyebabkan prosentase mahasiswa yang diperoleh 71,43 $\%$ khususnya pada pint 5, 6 dan 7 diantaranya adalah pada point 5 interaksi antara dosen, peneliti dan mahasiswa masih kurang karena ada sebagian mahasiswa yang masih rame sendiri sehingga tidak mempehatikan apa yang dosen sampaikan; Pada point 6 mahasiswa kurang percaya diri dalam menyampaikan pertanyaan atau 
pendapat; Pada point 7 mahasiswa tidak paham sintaks dari model pembelajaran active knowladge sharing (tabel 2 ).

Berdasarkan hasil wawancara yang diambil sampel dari 3 orang mahasiswa dapat disimpulkan bahwa sebagian besar mahasiswa sudah mulai tebiasa dan menyukai model pembelajaran Active knowledge sharing. Dengan menerapkan model pembelajaran Active knowledge sharing, mahasiswa lebih termotivasi untuk lebih percaya diri sehingga menyebabkan mahasiswa lebih aktif pada saat pembelajaran

Berdasarkan hasil dari pree test dan post test pada siklus 1 yang dilaksanakan oleh 26 mahasiswa sebelm dan setelah diterapkan model pembelajaran Active knowledge sharing diperoleh pebedaan nilai, dan mengalami peningkatan nilai post test setelah diterapkan model pembelajaran Active knowledge sharing.

Data untuk nilai hasil pree test diperoleh nilai terendah adalah 20 , sedangkan nilai tertinggi diperoleh mahasiswa adalah 70 dan nilai hasil post test diperoleh nilai terendah adalah 30 , sedangkan nilai tertinggi diperoleh mahasiswa adalah 90 dengan jumlah total nilai yang diperoleh adalah 1725 , dan rata-rata 66,35. Sehingga hasil ketuntasan kemampuan pemahaman konsep matematik mahasiswa dapat dilihat bedasakan hasil dari nilai post test diatas nilai KKM yaitu 70 diperoleh pada siklus I adalah 66,35. Dan hal tersebut menunjukkan bahawa terjadi peningkatan kemampuan pemahaman konsep matematik mahasiswa berdasarkan nilai yang diperoleh dari hasil post test. Dan hasil pengukuran dari N-Gaint diperoleh 0,32 kategori sedang. Oleh karena itu perlu dilanjutkan pada siklus II, karena belum mencapai ketuntasan hasil belajar.

d) Tahap keempat merupakan tahap terakhir pada siklus I yaitu refleksi Berdasarkan hasil refleksi pada siklus I maka dapat ditarik kesimpulan bahwa, hasil dari tes kemampuan pemahaman konsep matematik mahasiswa diperoleh nilai rata - rata mahasiswa dari hasil pree test adalah 51,92 dan nilai rata-rata post test adalah 66,35, serta perlu dilakukan tindak lanjut untuk memperoleh kemampuan konsep matematik mahasiswa sesuai dengan yang diaharapkan. Ada beberapa faktor yang menyebabkan nilai pree test dan post test mahasiswa masih di bawah KKM diantarannya adalah interaksi antara dosen, peneliti dan mahasiswa masih kurang karena ada sebagian mahasiswa yang masih rame sendiri sehingga tidak memperhatikan apa yang dosen sampaikan; Pada point 6 mahasiswa kurang percaya diri dalam menyampaikan pertanyaan atau pendapat; Pada point 7 mahasiswa tidak paham sintaks dari model pembelajaran active knowladge sharing. Oleh karena itu penelitian ini perlu dilanjutkan pada siklus Il dengan memperbaiki desain pembelajaran dengan sebaik mungkin, serta dosen (peneliti) lebih baik lagi dalam membimbing serta mengarahkan mahasiswa sehingga hasil yang dicapai oleh mahasiswa sesuai dengan harapan dari peneliti.

\section{Pelaksanaan pada Siklus II}

Berdasarkan hasil analisis dan refleksi dari siklus I diharapkan ada perbaikan pada siklus II, karena pada siklus I masih banyak kekurangan. Dan pelaksanaan pada siklus II dilaksanakan sebanyak 3 kali pertemuan dengan dihadiri oleh 26 mahasiswa, dengan 
menerapkan model pembelajaran active knowledge sharing Berdasarkan hasil refleksi dari siklus I maka perencanaan yang akan dilakukan pada siklus II meliputi:

a) Tahap Pertama, perencanaan meliputi peneliti menyusun Rencana Pelaksanaan Pembelajaran (RPP) dengan materi yang berbeda, menyiapkan sumber dan alat belajar diantarannya LCD, Proyektor. Menyiapkan lembar observasi, dan peneliti menyiapkan alat tes berupa tes kemampuan untuk mengetahui penguasaan konsep matematika mahasiswa. Tes berupa soal essay dengan jumlah 10 soal baik untuk soal pree test dan post test;

1) Peneliti menyiapkan materi bahan ajar yang harus dikerjakan siswa dengan membuat soal essay untuk pree test dan post test meliputi materi: membentuk persamaan differensial dari kumpulan garis lengkung, persamaan differensial tingkat 2, trayektori, metode operator $D$, persamaan differensial linier homogen tingkat $\mathrm{n}$ dengan koefisien fungsi $\mathrm{x}$.

2) Membuat silabus dan RPP.

3) Mengarahkan mahasiswa agar membentuk kelompok sebanyak 3-4 orang dalam satu kelompok.

b) Tahap Kedua, Pelaksanaan yaitu pada tahap ini penelitian dilaksanakan sebanyak 3 kali pertemuan. Tindakan pada siklus ke-II ini sesuai berdasarkan hasil pada siklus I dengan menerapkan model pembelajaran Active Knowledge sharing:

1) Pertemuan Pertama (11 Juni 2019) berlangsung selama $3 x @ 50$ menit membentuk persamaan differensial dari kumpulan garis lengkung, persamaan differensial tingkat 2, trayektori, metode operator $D$, persamaan differensial linier homogen tingkat $\mathrm{n}$ dengan koefisien fungsi $\mathrm{x}$ :

2) Pertemuan kedua (selasa, 18 Juni 2019) mahasiswa sudah bisa beradaptasi dan telah terlatih dengan pembelajaran pada pertemaun sebelumnya;

3) Pertemuan ketiga (selasa, 25 Juni 2019) dimana seluruh mahasiswa lebih bersemangat dalam mengikuti pembelajaran, sehingga secara keseluruhan semua mahasiswa memahami dan menjalankan semua alur sesuai dengan sintaks dari model pembelajaran active knowledge sharing, sehingga proses pembelajaran berjalan dengan tertib dan lancar. Di akhir pembelajaran peneliti dan tim memberikan soal post test kepada seluruh mahasiswa dalam bentuk essay sebanyak 10 soal.

c) Tahap Ketiga, Pengamatan (Observing) Pada tahapan ini dilakukan observasi dengan menggunakan lembar observasi terhadap pelaksanaan tindakan yang sudah dilakukan pada siklus II serta didapatkan hasil wawancara dengan mahasiswa dan hasil tes kemampuan pemahaman konsep matematik pada mata kuliah persamaan differensial.Berikut ini adalah data dari hasil. Observasi, wawancara dan tes kemampuan pemahaman konsep matematika mahasiswa:

Tabel 3. Hasil observasi Aktivitas Mahasiswa pada siklus II 


\begin{tabular}{|c|c|c|c|c|c|}
\hline & & SB & $\mathrm{B}$ & C & $\mathrm{K}$ \\
\hline 1 & Kesiapan Menerima Pembelajaran & $\sqrt{ }$ & & & \\
\hline 2 & $\begin{array}{l}\text { Mendengarkan penjelasan tentang } \\
\text { kompetensi yang hendak dicapai }\end{array}$ & $\sqrt{ }$ & & & \\
\hline 3 & Mengikuti proses pembelajaran & & $\sqrt{ }$ & & \\
\hline 4 & Keterlibatan dalam pembelajaran & & $\sqrt{ }$ & & \\
\hline 5 & $\begin{array}{l}\text { Interaksi antara Peneliti, mahasiswa, } \\
\text { dan materi pembelajaran. }\end{array}$ & $\sqrt{ }$ & & & \\
\hline 6 & $\begin{array}{l}\text { Mengemukakan pendapat ketika } \\
\text { diberikan kesempatan untuk bertanya }\end{array}$ & & $\sqrt{ }$ & & \\
\hline 7 & Kerjasama tim & & $\sqrt{ }$ & & \\
\hline \multicolumn{2}{|c|}{ Jumlah } & \multicolumn{4}{|c|}{24} \\
\hline \multicolumn{2}{|c|}{ Prosentase } & \multicolumn{4}{|c|}{85,71} \\
\hline \multicolumn{2}{|c|}{ Kualifikasi } & \multicolumn{4}{|c|}{ Sangat baik } \\
\hline
\end{tabular}

hasil observasi Aktivitas Mahasiswa pada siklus II menejelaskan bahwa skor yang diperoleh dari beberapa aspek diperoleh 24 , dan prosentase diperoleh 85,71 \% dengan kategori Sangat baik oleh karena itu tidak perlu dilakukan perbaikan (tabel 3). Dan Berdasarkan hasil wawancara yang diambil sampel dari 3 orang mahasiswa dapat disimpulkan bahwa sebagian besar mahasiswa sudah terbiasa dan menyukai model pembelajaran Active knowledge sharing karena dipengaruhi oleh beberapa faktor diantarannya mahasiswa sudah mengerti dan memahami sintaks sehingga dapat mengikuti proses pembelajaran dengan baik, mahasiswa lebih termotivasi untuk lebih percaya diri sehingga menyebabkan mahasiswa lebih aktif bertanya pada saat pembelajaran berlangsung.

Dan berdasarkan Hasil Test kemampuan pemahaman konsep matematik pada siklus II yang diperoleh dari hasil pree test dan post test sebanyak 26 mahasiswa diperoleh nilai hasil pree test adalah 25 , sedangkan nilai tertinggi diperoleh mahasiswa adalah 75 dan nilai hasil post test diperoleh nilai terendah adalah 75 , sedangkan nilai tertinggi diperoleh mahasiswa adalah 100 dengan jumlah total nilai yang diperoleh adalah 2270 , dan rata-rata 87,31. Sehingga hasil ketuntasan kemampuan pemahaman konsep matematik mahasiswa dapat dilihat bedasakan hasil dari nilai post test diatas nilai KKM yaitu 70 diperoleh pada siklus II adalah 87,31. Dan hal tersebut menunjukkan bahawa terjadi peningkatan kemampuan pemahaman konsep matematik mahasiswa berdasarkan nilai yang diperoleh dari hasil post test. Dan hasil pengukuran dari NGaint diperoleh 0,72 kategori tinggi.

d) Tahap terakhir Berdasarkan hasil refleksi pada siklus II maka dapat ditarik kesimpulan bahwa, hasil dari tes kemampuan pemahaman konsep matematik mahasiswa diperoleh nilai rata - rata dari hasil preetest adalah 57,31 dan nilai rata-rata post test adalah 87,31, karena hasil yang diperoleh pada siklus II seluruh mahasiswa sudah memenuhi KKM, maka penelitian ini tidak perlu dilanjutkan pada siklus selanjutnya cukup sampai dengan siklus II saja.

Berdasarkan hasil pada siklus I dan II telihat bahwa hasil observasi dan test kemampuan pemahaman konsep matematik mahasiswa mengalami peningkatan dengan menerapkan 
model pembelajaran active knowledge sharing. Dan hal tersebut diperkuat hasil dari peningkatan setiap siklus. Penelitian ini sejalan dengan hasil penelitian (Nasir \& Febriana, 2017; Nur, \& Anna, 2016; Sopinal, 2018; dan Wahyuningtyas, 2013) dengan menerapkan model pembelajaran active knowledge sharing dapat meningkatkan pemahaman konsep.

\section{SIMPULAN}

Berdasarkan hasil penelitian yang telah dilakukan dengan menerapkan model pembelajaran Active knowledge sharing pada pembelajaran persamaan Differensial di tingkat II Semester 4 Pada Mata Kuliah Persamaan differensial, mahasiswa merasakan perbedaan dalam pembelajaran. Mahasiswa lebih percaya diri, dan lebih aktif di kelas hal tersebut ditunjukkan dengan berani mengemukakan pendapat atau berani menanyakan bila dirasa tidak paham dengan materi yang disampaikan, serta kelebihan dari model pembelajaran Active knowledge sharing sendiri adanya kolaborasi melibatkan peserta didik bukan hanya mental tetapi juga melibatkan fisik, memberikan efek sosial dari belajar aktif. Maka dapat ditarik kesimpulan dengan menerapkan model pembelajaran Active knowledge sharing dapat meningkatkan kemampuan pemahaman konsep matematik mahasiswa.

Hal ini berdasarkan dari hasil pada siklus I diperoleh nilai rata-rata tes kemampuan pemahaman konsep matematik mahasiswa sebesar 66,35, Dan siklus II diperoleh nilai ratarata hasil tes kemampuan pemahaman konsep matematik mahasiswa sebesar 87,31. Hal ini menunjukkan bahwa hasil tes kemampuan pemahaman konsep matematik mahasiswa mengalami peningkatan dengan menerapkan model pembelajaran Active knowledge sharing membuat mahasiswa menjadi lebih aktif dan dapat lebih mudah mempelajari materi pesamaan differensial. Hal ini dapat dilihat dari hasil observasi dan hasil wawancara mahasiswa yang menunjukkan bahwa lebih aktif sehingga dapat meningkatkan kemampuan pemahaman konsep matematik mahasiswa.

\section{DAFTAR PUSTAKA}

Ariasa, I Kd, Wiyasa, I Km Ngr, Kristiantari, M G Rini,dkk. (2014). Pengaruh Model Pembelajaran Active Knowledge Sharing Terhadap Hasil Belajar Matematika Mahasiswa Kelas V Sd Gugus Peliatan Ubud Tahun Ajaran 2013/2014. Jurnal Mimbar PGSD Universitas Pendidikan Ganesha urusan PGSD. 2(1), 1-11 http://ejournal.undiksha.ac.id/index.php/JJPGSD/article/download/2225/1925.

Hamruni. (2009). Strategi dan Model-model Pembelajaran Aktif Menyenangkan. Yogyakarta: Fakultas Tarbiyah UIN Sunan Kalijaga.

Hasbullah. (2011). Dasar-dasar Ilmu Pendidikan. Jakarta: Rajawali Pers Jatmiko. (2018). Kesulitan siswa dalam memahami pemecahan masalah matematika. Jurnal Ilmiah Pendidikan Matematika, 3(1), 17-20. DOI: http://dx.doi.org/10.26877/jipmat.v3i1.2285 
Jeon, S.-H., Kim, Y.-G., \& Koh, J. (2011). Individual, social, and organizational contexts for active knowledge sharing in communities of practice. Expert Systems with Applications, 38(10), 12423-12431. doi:10.1016/j.eswa.2011.04.023

Mutmainah, S. (2015). Pengaruh Strategi Active Knowledge Sharing Terhadap pemahaman konsep matematik mahasiswa. Skipsi. Tidak dipublikasokan. Universitas Islam Negeri Syarif Hidayatulloh Jakarta.

Nasir, R., Rahmi \& Febriana, R, (2017). Pengaruh Penerapan Strategi Pembelajaran Aktif Tipe Aktive Knowledge Sharing Disertai Kuis Terhadap Pemahaman Konsep Matematis Siswa Kelas X SMA DR. H. Abdullah Ahmad PGAI Padang. LEMMA, 3(2), 1-9, DOI: https://doi.org/10.22202/jl.2017.v3i1.1904

Ni'mah, A. (2017). Efektivitas Model Pembelajaran Active Knowledge Sharing Dengan Pendekatan Saintifik Tehadap Kemampuan Reprsentasi Matematis Peserta Didik Materi Segiempat MTs Tarbiyatul ISLAMIYAH Batangan Tahun Pelajaran 2016/2017. Disertasi. Tidak dipublikasikan. UIN Walisongo Semarang http://eprints.walisongo.ac.id/8642/1/skripsi.pdf

Panjaitan, D. J. (2017). Meningkatkan Hasil Belajar Siswa Dengan Metode Pembelajaran Langsung. JURNAL MATHEMATIC PAEDAGOGIC, 1(1), 83-90. DOI: https://doi.org/10.36294/jmp.v1i1.158

Qomaria N , Anna, F , \& Drajat F. (2016). Pengaruh Strategi Pembelajaran Aktif Tipe Active Knowledge Sharing Terhadap Komunikasi Matematika Siswa Kelas VIII SMP NEGERI 5 Tebing Tinggi Tahun Pelajaran 2015/2016. Alumni STKIP-PGRI Lubuklinggau Dosen Prodi

Matematika http://mahasiswa.mipastkipllg.com/repository/ARTIKEL\%20NUR\%20QOMARIA\%2012 3.pdf

Sopinal, R. (2018). Peningkatan hasil belajar matematika siswa smk melalui strategi pembelajaran active knowledge sharing. Jurnal Pendidikan Tambusai, 2(1), 98-111. doi.org/10.31004/jptam.v2i1.61

Wahyuningtyas, E. (2013). Penerapan Strategi Active Knowledge Sharing Untuk Meningkatkan Keaktifan Siswa Pada Mata Pelajaran Ekonomi Kelas VII SMP Negeri 4 Malang. Skripsi. tidak dipublikasikan. Universiras Negeri Malang. http://library.um.ac.id/ptk/index.php/index.php?mod=detail\&id=63434. 